\title{
RELIABILITY OF DIFFERING DENSITIES OF SAMPLE GRIDS USED FOR THE MONITORING OF FOREST CONDITION IN EUROPE
}

\author{
MICHAEL KÖHL, JOHN L. INNES and EDGAR KAUFMANN \\ Swiss Federal Institute for Forest, Snow and Landscape Research, Zürcherstrasse 111, CH-8903 \\ Birmensdorf, Switzerland.
}

(Received: February 1993; revised: July 1993)

\begin{abstract}
Concern about the possible deterioration of forest health led to the establishment in the 1980 s of inventories of forest condition throughout Europe. International standardisation of the programmes was sought and a number of recommendations were made concerning sampling and assessment procedures. One of the most important rulings was that the assessment should be made on a systematic grid, the minimum density of which was $16 \times 16 \mathrm{~km}$. However, many countries adopted denser sampling grids, with $4 \times 4 \mathrm{~km}$ being used in several countries and $1 \times 1 \mathrm{~km}$ being used in the Netherlands. With five or more years of monitoring completed, there is a growing belief that a rapid and irreversible decline in forest health is not occurring. Consequently, some countries/regions are seeking to reduce their annual investment in forest health monitoring.

The precision of national/regional estimates of forest health can be directly related to the sample size. As the sample size decreases, so also does the precision of the estimates. This is illustrated using data collected in Switzerland in 1992 and using grid densities of $4 \times 4 \mathrm{~km}, 8 \times 8 \mathrm{~km}, 12 \times 12 \mathrm{~km}$ and $16 \times 16 \mathrm{~km}$. The value of the data is dependent on the sample size and the degree to which it is broken down (by region or species). The loss of precision associated with most subdivisions at the $8 \times 8 \mathrm{~km}$ grid level remains acceptable, but a sharp deterioration in the precision occurs at the $12 \times 12 \mathrm{~km}$ and $16 \times 16 \mathrm{~km}$ grid levels. This has considerable implications for the interpretation of the inventories from those countries using a $16 \times 16 \mathrm{~km}$ grid. In Switzerland, a reduction from the current $4 \times 4 \mathrm{~km}$ grid to an $8 \times 8 \mathrm{~km}$ grid (i.e. $75 \%$ reduction in sample size) would have relatively little impact on the overall results from the annual inventories of forest health.
\end{abstract}

\section{Introduction}

Since 1984, surveys of forest condition have been conducted in several European countries. The United Nations Economic Commission for Europe, under the auspices of the Convention of Long Range Transboundary Air Pollution, has suggested that a grid size no wider than $16 \mathrm{~km}$ is required for forest damage inventories. However, many countries have adopted denser grids, ranging down to the $1 \mathrm{~km}$ grid used for some years in the Netherlands. The size of the programme has gradually increased, and in 1991 it involved over 30 countries, with Canada and the United States of America acting as observers. Although the results of the programme are widely cited, they are subject to misinterpretation and a number of problems exist with the data. One problem is that of the consistency of observations between countries and between years. This has been examined in a series of papers (Lick and Krapfenbauer, 1986; Neumann and Stowasser, 1987; Innes 1987, 1988a, 1989b, 1990, 1992 et al., 1993; Landmann, 1989; Mahrer, 1989; Köhl, 1991; Schadauer, 1991; Bouhot et al., 1992) and it is apparent that there are major difficulties involved with the comparison of results obtained in different countries. 
Although the sampling design has been criticised by Innes (1988a, 1990), Neumann (1989) and others, it has been generally (but erroneously) accepted that the observation of a fixed number of trees at each point on a $16 \mathrm{~km}$ net provides a representative picture of the condition of forests in a country. This is clearly questionable in some European countries which are so small or have such a low percentage of land covered with forests that such a grid produces only a few sample points. Given the diversity of tree species and stand characteristics that are found in individual countries, the sample sizes that are required to produce estimates of forest condition that are both representative and meaningful may be considerable. Further difficulties may arise when data describing forest condition are broken down into individual regions, resulting in particularly small sample sizes for the rarer species.

There is a considerable amount of noise present in forest health data sets (Köhl, 1993; Köhl and Gertner, 1992; Innes, 1993) making annual comparisons problematical. One way to reduce sampling errors is by having a sufficient sample size for the monitoring programme. Observer bias can be reduced by intensive training and control, but not by an increase of sample size. Given the limitations imposed by the application of a rigid fixed grid with fixed number of sample trees per plot, it is perhaps surprising that any attempt is made to interpret the results of forest damage inventories obtained in some areas.

It is increasingly recognised that the inventories are not producing information on cause-effect relationships (Schlaepfer, 1992), and this, together with increasing financial pressures, is making some countries/regions consider the possibility of reduced sample plot densities. For example, between 1989 and 1993, the state of Baden-Württemberg in Germany alternated between a $4 \times 4 \mathrm{~km}$ net and a $16 \times 16 \mathrm{~km}$ net.

The alternation of different grid densities or the simple reduction from a dense net to a less dense grid creates a number of statistical problems that do not appear to have been adequately addressed. This is particularly important when, at national and international levels, results continue to be presented for relatively small sampling units. In this paper, we examine the sampling errors associated with different sample plot densities, firstly from a theoretical basis and then using data collected in the Swiss forest damage inventory. Although the topography of Switzerland means that the forests are relatively diverse, $70 \%$ of the forest trees comprise only three species: Norway spruce (Picea abies (L.) Karst.), silver fir (Abies alba Mill.) and European beech (Fagus sylvatica L.) (EAFV, 1988). Marked variations occur between mountain and plateau forests and in different regions in Switzerland, and the data have been analysed both in terms of the national statistics and in relation to specific areas. 


\section{Theoretical Basis}

The true health condition of a single tree varies between the extremes 'healthy' and 'dead'. Between these endpoints there is an infinite number of grades which characterize the different stages of condition. This situation can be described by a metric variable that is limited by the values ' 0 ' and ' 1 '. As a direct assessment of the health condition of a tree is not possible, auxiliary (surrogate) variables have to be defined. These variables should have a strong relation to the actual health of the tree. Crown transparency (formerly termed needle/leaf loss) is such an auxiliary variable, although the factors influencing it are complex. As crown transparency cannot be readily measured, it is assessed visually. The problems surrounding visual assessments of crown transparency have been described by many authors (Lick and Krapfenbauer, 1986; Neumann and Stowasser, 1987; Kublin, 1987; Köhl, 1991; 1993; Innes, 1988a; 1988b) and are not considered here. We must assume that crown transparency is assessed without errors.

The degree of forest health condition can be described by different variables. The scale of the variables is decisive for the analytical procedures that are applied to the data. The statistical procedures applicable to continuous variables differ from those used for discrete variables. For mean crown transparency (range: 0-100\%), a variable with continuous scale is assumed. As crown transparencies are assessed in $5 \%$ classes, an analysis based on continuous scaling is only valid if the relationship between the true, relative crown transparency and the ocular estimate is linear (Schöpfer and Hradetzky, 1983). The estimation of sampling errors for the mean values of crown transparencies is described by Köhl and Kaufmann (1993).

Crown transparencies can be aggregated into classes. The UN Economic Commission for Europe has suggested the following four classes:

class 0: $\quad 0-10 \%$ transparency

class 1: $\quad 11-25 \%$ transparency

class 2: $\quad 26-60 \%$ transparency

class 3: $>60 \%$ transparency

The aggregation of crown transparencies into defoliation classes results in an ordinal scale. The median characterizes an ordinal distribution only if there is a sufficient number of classes. As only four classes are constructed in forest health monitoring, the estimation of proportions is more valid than the use of a median.

Mandallaz et al. (1986) grouped the visual assessments into two classes for analyses with logistic models. However, change over time must be assessed at a more detailed scale. We will describe the special case of two categories as an introduction to the estimation of proportions and than expand the theory to more than two classes.

The estimation of two classes, e.g., the two categories 'healthy' and 'not healthy' is straightforward. A variable $y$ is defined, that takes the value ' 1 ', if the observation is in class $K$, and ' 0 ', if the observation is in class $K^{\prime}$ and not in class $K$. The proportion $p$ can be estimated as follows: 


$$
\bar{y}=\frac{\Sigma y_{i}}{n}=\frac{a}{n}=p
$$

with variance

$$
s^{2}=\frac{\Sigma\left(y_{i}-\bar{y}\right)^{2}}{n-1}=\frac{n}{n-1} p(1-p)
$$

where: $p=$ proportion of elements in class $K ; a=$ number of elements in class $K$; $n=$ total number of observations (where $n \ll N, N=$ size of population).

It is sufficient to estimate $p$ and construct a confidence interval for $p$. The estimate of $p$ implies the estimate of the proportion $q$ of class $K^{\prime}$, as

$$
q=1-p
$$

The variance of $p, \operatorname{var}(p)$, and the standard error, $s_{p}$, are

$$
\begin{aligned}
& \operatorname{var}(p)=\frac{p q}{n-1} \\
& s_{p}=\sqrt{\frac{p q}{n-1}}
\end{aligned}
$$

The confidence limits for $p$ depend on the distribution of $p$. Further details are provided by Cochran (1977) and Kish (1965). One form of the normal approximation to the confidence limits of $p$ is

$$
p \pm[t \sqrt{p q /(n-1)}+1 / 2 n]
$$

where $t=$ normal deviate corresponding to the confidence probability.

The last term on the right side is a correction for continuity, which is necessary as $p$ is not a continuous variable. According to Cochran (1977), the omission of the correction for continuity results in confidence intervals that are too short. The possibilities for the construction of confidence intervals of $p$ are discussed by Dees (1988) and Burk (1987). The normal approximation gives sufficient results only for situations where $p$ and $n$ are not too small. Cochran $(1977$, p. 58) gives the smallest values for the product of $n$ and $p$, which can be used as working rules for deciding when the normal approximation may be used.

When estimating proportions, it should be remembered that the trees are assessed as groups on plots. The size of the groups is not constant and the estimation of $p$ and the variance of $p$ must therefore be modified as follows.

$$
\begin{aligned}
& p=\frac{\Sigma a_{i}}{\Sigma m_{i}} \\
& \operatorname{var}(p)=\frac{1}{n \bar{m}^{2}} \frac{\Sigma a_{i}^{2}-2 p \Sigma a_{i} m_{i}+p^{2} \Sigma m_{i}^{2}}{n-1}
\end{aligned}
$$

where $a_{i}=$ number of elements in class $K$ on plot $i ; m_{i}=$ number of elements on plot $i ; n=$ number of plots; and 
$\bar{m}=\frac{\Sigma m_{i}}{n}=$ average number of elements on plots.

The estimation of proportions for more than two classes can be considered as a special case of the estimation of two classes (Cochran, 1977). It is assumed that $k$ estimates are conducted for two classes each. The proportions of the four transparency classes can be defined as:

$\begin{array}{lll}\text { estimate } 1: & 0 \leq p \leq 10 \% & q>10 \% \\ \text { estimate } 2: & 11 \leq p \leq 25 \% & 0 \leq q \leq 10 \% \text { and } q>25 \% \\ \text { estimate } 3: & 26 \leq p \leq 60 \% & 0 \leq q \leq 25 \% \text { and } q>60 \% \\ \text { estimate } 4: & p>60 \% & 0 \leq q \leq 60 \%\end{array}$

The variance of the proportions are calculated as shown above.

One approach to the estimation of confidence intervals is to consider each cell proportion versus the remaining ones as a binomial distribution. A set of binomial confidence estimates is made for the individual cell proportions. According to Quesenberry and Hurst (1964) "this approach does not allow one to assess the value of the confidence coefficient for the entire set of intervals, or to make statements concerning the relative values of the proportions".

The global confidence probability has to be distributed to the $k$ interval estimates for the estimation of simultaneous confidence intervals for multinomial proportions. Multinomial confidence intervals have been described by Gold (1963), Quesenburry and Hurst (1964) and Goodman $(1964,1965)$. The methods presented here use the normal approximation, the difference between the methods being the derivation of the simultaneous confidence probability. We have restricted ourselves to a method based on the Bonferroni inequality (Miller, 1981). In statistical inference, the Bonferroni method is widely used for the adjustment of the significance level for multiple comparisons (Köhl, 1990a).

Applying the Bonferroni method, the global error probability $\alpha$ for all confidence intervals is distributed equally to the $k$ estimates. For each of the $k$ confidence intervals $\alpha_{z}$ is used instead of $\alpha$.

$$
\alpha_{z}=\frac{\alpha}{k}
$$

where: $\alpha_{z}=$ adjusted error probability in class $k(z=1, \ldots, k) ; k=$ number of classes; $\alpha=\Sigma \alpha_{z}$.

Given a global error probability of $\alpha=0.05$, the adjusted probability level for four classes is $\alpha_{z}=0.05 / 4=0.0125$. The normal deviate $t$ corresponding to $\alpha_{z}$ has to be taken from a $t$-table (e.g., Zar, 1984, p. 484), according to the appropriate degrees of freedom, and used for the estimation of the confidence intervals. Selected values of the $t$-distribution are given in Table I.

The confidence intervals presented below were obtained by using a global confidence probability $(100-\alpha)=95 \%$. Hence the endpoints of the $k=4$ confidence intervals are calculated with $\alpha_{z}=0.0125$.

$$
p \pm\left[t_{\mathrm{df} ; \alpha_{z} ; 2-\text { sided }} \sqrt{\operatorname{var}(p)}+1 / 2 n\right]
$$


TABLE I

$\alpha$-Quantiles of the $t$-distribution.

\begin{tabular}{lcc}
\hline \multicolumn{1}{c}{$\alpha$} & $t_{\infty ; \alpha ; 2-\text { sided }}$ & $t_{120 ; \alpha ; 2-\text { sided }}$ \\
\hline 0.1 & 1.645 & 1.658 \\
0.05 & 1.960 & 1.980 \\
0.025 & 2.250 & 2.300 \\
0.02 & 2.326 & 2.358 \\
0.0125 & 2.510 & 2.600 \\
0.01 & 2.576 & 2.617 \\
0.005 & 2.810 & 2.900 \\
0.0025 & 3.030 & 3.100 \\
0.002 & 3.090 & 3.160 \\
\hline
\end{tabular}

\section{Field Methods}

Data were collected from a $4 \times 4 \mathrm{~km}$ grid across Switzerland. In contrast to other forest damage inventories, which are based on fixed numbers of trees per plot (Köhl, 1990b), plots were based on fixed areas, with all trees with a diameter at breast height (dbh) of $>12 \mathrm{~cm}$ being assessed within a radius of $7.98 \mathrm{~m}$ and additional trees with a dbh of $>36 \mathrm{~cm}$ within a radius of $12.62 \mathrm{~m}$ also being included. In each case, trees were included if their centers lay within the radius. The sampling design followed that of the Swiss national forest inventory (NFI), which was conducted between 1983 and 1985 (Zingg, 1988). As studies conducted during the first NFI and elsewhere (e.g. Nicholas et al., 1991) have shown that the assessment of the social class of trees (relative status of trees taking into account competition) is prone to errors, all trees within the relevant size class, regardless of social class, were included. This again differs from many other countries, where sub-canopy and suppressed trees are excluded from the assessments. On average, 13 to 14 trees were assessed per plot.

Crown transparencies were assessed from the ground by comparison with standard photographs (Müller and Stierlin, 1990). Crown transparencies were recorded in $5 \%$ classes. For the purposes of the analyses, data were aggregated into the four classes used by the United Nations Economic Council for Europe (see above). For this investigation, the 1992 Swiss forest damage inventory data were used (Brassel and Schwyzer, 1992). The data included 7940 trees assessed on 678 plots across Switzerland. 


\section{Results and Interpretation}

Variation between different grid densities was assessed by taking the $4 \times 4 \mathrm{~km}$ as a base and looking at all possible grids of varying densities $(8 \times 8 \mathrm{~km}, 12 \times 12 \mathrm{~km}$, and $16 \times 16 \mathrm{~km}$ ). The number of grids was therefore dependent on the density, with only one being possible for the $4 \times 4 \mathrm{~km}$ level (involving all available data), four being possible for the $8 \times 8 \mathrm{~km}$ level, nine being possible for the $12 \times 12 \mathrm{~km}$ level, and 16 being possible for the $16 \times 16 \mathrm{~km}$ level. As all subgrids are subsamples of the $4 \times 4 \mathrm{~km}$ level the observations are not independent. The use of independent samples of different grid sizes could have resulted in a much higher variability.

As the trees are not independently assessed but selected on plots, the effect of clustering had to be taken into account.

Ratios and variances are weighted by basal areas of trees. This weighting method is widely applied in the analysis of forest health monitoring data (Schöpfer and Hradetzky, 1983; Brassel and Schwyzer, 1992).

Results will be presented for the total population and the subsets 'geographical units' and 'single tree species'. These are the units used in the annual reports of forest condition in Switzerland, and similar data are presented in the annual reports of other countries and in international reports. The five regions of Switzerland are Jura (JU), plateau region (ML), Prealps (VA), Alps (AL) and southern slopes of the Alps (AS) and are defined according to growth conditions (EAFV, 1988).

The most common tree species in Switzerland are spruce, fir, and beach. To demonstrate the effect of different grid sizes for a relatively rare tree species, the results for oak (Quercus spp.) are also presented.

In this investigation the focus has been put on sampling errors. Non-sampling errors like observer bias are not taken into account, but may have an effect on the results.

\subsection{NUMBER OF OBSERVATIONS}

A total of 678 forested and accessible plots are located in the $4 \times 4 \mathrm{~km}$ grid. In the geographical regions, the number of plots varies between 223 (Alps) and 79 (southern slopes of the Alps). Spruce can be found on 457 plots (67\%), fir on 186 plots (27\%), beech on 286 plots (42\%), and oak on 55 plots (8\%). The highest proportion of trees is located in the Alps (2534 trees or 32\%), whereas on the southern slopes of the Alps only 794 trees $(10 \%)$ are assessed. The most frequent tree species is spruce ( 3353 trees or $42 \%$ ); oaks represent only 1.5 percent of the total number of trees. As the calculation of the results is based on the plot level, the number of plots is of great importance. Nevertheless the number of trees provides a valuable indication of the reliability of the results. The number of plots and the number of trees for the total population, subsets and different grid levels are shown in Table II. As only one grid is possible for the $4 \times 4 \mathrm{~km}$ level, no maximum or minimum values are presented and the mean values represent the actual numbers of plots included in the assessments. 
TABLE II

a. Number of plots for the total population, subpopulations and grid levels.

\begin{tabular}{|c|c|c|c|c|}
\hline \multirow[t]{2}{*}{ Grid } & \multirow[t]{2}{*}{ Stratum } & \multicolumn{3}{|c|}{ Number of plots } \\
\hline & & MIN & MEAN & $\overline{M A X}$ \\
\hline \multirow[t]{10}{*}{$4 \times 4 \mathrm{~km}$} & TOTAL & & 678 & \\
\hline & $\mathrm{JU}$ & & 131 & \\
\hline & ML & & 129 & \\
\hline & VA & & 116 & \\
\hline & $\mathrm{AL}$ & & 223 & \\
\hline & AS & & 79 & \\
\hline & SPRUCE & & 457 & \\
\hline & FIR & & 186 & \\
\hline & BEECH & & 286 & \\
\hline & OAK & & 55 & \\
\hline \multirow[t]{10}{*}{$8 \times 8 \mathrm{~km}$} & TOTAL & 161 & 169.50 & 177 \\
\hline & $\mathrm{JU}$ & 30 & 32.75 & 35 \\
\hline & ML & 28 & 32.25 & 39 \\
\hline & $\mathrm{VA}$ & 25 & 29.00 & 35 \\
\hline & $\mathrm{AL}$ & 52 & 55.75 & 60 \\
\hline & AS & 17 & 19.75 & 25 \\
\hline & SPRUCE & 104 & 114.25 & 119 \\
\hline & FIR & 42 & 46.50 & 49 \\
\hline & BEECH & 63 & 71.50 & 76 \\
\hline & OAK & 8 & 13.75 & 18 \\
\hline \multirow[t]{10}{*}{$12 \times 12 \mathrm{~km}$} & TOTAL & 68 & 75.33 & 85 \\
\hline & JU & 11 & 14.56 & 18 \\
\hline & ML & 12 & 14.33 & 20 \\
\hline & VA & 10 & 12.89 & 18 \\
\hline & $\mathrm{AL}$ & 21 & 24.78 & 31 \\
\hline & AS & 5 & 8.78 & 14 \\
\hline & SPRUCE & 42 & 50.78 & 64 \\
\hline & FIR & 14 & 20.67 & 27 \\
\hline & BEECH & 25 & 31.78 & 38 \\
\hline & OAK & 3 & 6.11 & 8 \\
\hline \multirow[t]{10}{*}{$16 \times 16 \mathrm{~km}$} & TOTAL & 33 & 42.38 & 50 \\
\hline & $\mathrm{JU}$ & 4 & 8.19 & 12 \\
\hline & ML. & 3 & 8.06 & 11 \\
\hline & VA & 1 & 7.25 & 13 \\
\hline & $\mathrm{AL}$ & 10 & 13.94 & 18 \\
\hline & AS & 1 & 4.94 & 9 \\
\hline & SPRUCE & 21 & 28.56 & 34 \\
\hline & FIR & 8 & 11.63 & 18 \\
\hline & BEECH & 14 & 17.87 & 23 \\
\hline & OAK & 1 & 3.44 & 8 \\
\hline
\end{tabular}


TABLE II

b. Number of trees for the total population, subpopulations and grid levels.

\begin{tabular}{|c|c|c|c|c|}
\hline \multirow[t]{2}{*}{ Grid } & \multirow[t]{2}{*}{ Stratum } & \multicolumn{3}{|c|}{ Number of trees } \\
\hline & & MIN & MEAN & MAX \\
\hline \multirow[t]{10}{*}{$4 \times 4 \mathrm{~km}$} & TOTAL & & 7940 & \\
\hline & $\mathrm{JU}$ & & 1477 & \\
\hline & ML & & 1570 & \\
\hline & VA & & 1565 & \\
\hline & $\mathrm{AL}$ & & 2534 & \\
\hline & AS & & 794 & \\
\hline & SPRUCE & & 3353 & \\
\hline & FIR & & 884 & \\
\hline & BEECH & & 1444 & \\
\hline & OAK & & 116 & \\
\hline \multirow[t]{10}{*}{$8 \times 8 \mathrm{~km}$} & TOTAL & 1877 & 1985.00 & 2027 \\
\hline & $\mathrm{JU}$ & 324 & 369.25 & 393 \\
\hline & $\mathrm{ML}$ & 294 & 392.50 & 488 \\
\hline & VA & 311 & 391.25 & 453 \\
\hline & $\mathrm{AL}$ & 591 & 633.50 & 665 \\
\hline & AS & 177 & 198.50 & 236 \\
\hline & SPRUCE & 743 & 838.25 & 990 \\
\hline & FIR & 208 & 221 & 240 \\
\hline & BEECH & 318 & 361 & 434 \\
\hline & OAK & 18 & 29 & 39 \\
\hline \multirow[t]{10}{*}{$12 \times 12 \mathrm{~km}$} & TOTAL & 743 & 882.22 & 999 \\
\hline & $\mathrm{JU}$ & 110 & 164.11 & 227 \\
\hline & ML & 134 & 174.44 & 251 \\
\hline & VA & 118 & 173.89 & 267 \\
\hline & $\mathrm{AL}$ & 218 & 281.56 & 335 \\
\hline & AS & 48 & 88.22 & 141 \\
\hline & SPRUCE & 307 & 372.56 & 430 \\
\hline & FIR & 60 & 98.22 & 136 \\
\hline & $\mathrm{BEECH}$ & 126 & 160.44 & 202 \\
\hline & OAK & 3 & 12.89 & 25 \\
\hline \multirow[t]{10}{*}{$16 \times 16 \mathrm{~km}$} & TOTAL & 388 & 496.25 & 569 \\
\hline & $\mathrm{JU}$ & 32 & 92.31 & 163 \\
\hline & ML & 39 & 98.12 & 146 \\
\hline & VA & 10 & 97.81 & 187 \\
\hline & AL & 117 & 158.37 & 197 \\
\hline & AS & 6 & 49.63 & 96 \\
\hline & SPRUCE & 123 & 209.56 & 290 \\
\hline & FIR & 28 & 55.25 & 81 \\
\hline & BEECH & 61 & 90.25 & 158 \\
\hline & OAK & 2 & 7.25 & 16 \\
\hline
\end{tabular}


TABLE III

Estimated proportions (minimum and maximum values) for different grid levels (total population).

\begin{tabular}{lrrrrrrr}
\hline Class & $4 \times 4 \mathrm{~km}$ & \multicolumn{2}{c}{$8 \times 8 \mathrm{~km}$} & \multicolumn{2}{c}{$12 \times 12 \mathrm{~km}$} & \multicolumn{2}{c}{$16 \times 16 \mathrm{~km}$} \\
& & $\min$ & $\max$ & $\min$ & $\max$ & $\min$ & $\max$ \\
\hline 0 & 37.5 & 35.7 & 39.6 & 32.5 & 43.8 & 31.8 & 41.4 \\
1 & 46.7 & 44.4 & 49.1 & 42.9 & 49.8 & 40.7 & 52.3 \\
2 & 13.7 & 12.9 & 14.8 & 11.4 & 16.4 & 8.7 & 17.3 \\
3 & 2.1 & 1.8 & 2.5 & 1.1 & 3.2 & 0.7 & 3.5 \\
\hline
\end{tabular}

The number of observations is proportional to the grid density. On the basis of the $4 \times 4 \mathrm{~km}$ grid, several grids of the same but lower density can be defined. This leads to equal grid levels having differing numbers of observations. A substantial decrease of the number of plots can be observed for the lower grid levels. 678 plots are present on the $4 \times 4 \mathrm{~km}$ grid level and this is reduced to only 42 plots (mean) at the $16 \times 16 \mathrm{~km}$ grid level. Even on the $8 \times 8 \mathrm{~km}$ grid level the available number of plots is questionable for some of the subsets. On the $16 \times 16 \mathrm{~km}$ grid level the results for most subsets are meaningless, as the low number of observations leads to extremely wide confidence intervals. In some cases (VA, AS, oak) only one observation is available, and sampling errors and confidence intervals cannot be calculated. A similar pattern is evident when the numbers of trees in each net are examined (Table IIb). The degree of variation is particularly apparent at the lower plot densities and several of the grids clearly provide very questionable data.

The relative range of the number of observations depends on the grid level. At the same grid level, some grids may allow the calculation of reliable results, others may not. The fact that one grid may be optimal for some subsets but suboptimal for others severely complicates the selection of an appropriate subgrid.

\subsection{PROPORTIONS}

The total population proportions obtained for different grid densities are shown in Figure 1, using the standard method of presentation. The uppermost bar gives the results for the 1992 forest damage survey in Switzerland based on all 7940 trees. The variation of the proportions in the four classes increases with the width of the grid. The mean proportion, together with the maximum and minimum values, for the four transparency classes are presented in Figure 2 for each grid density. The increase in the range of proportions with increasing grid width is apparent. This is confirmed in Table III, where the minimum and maximum proportions for each class and each grid are shown. The results vary by more than 10 percent for single classes. The proportion of trees in class 0 varies from $31.8 \%(16 \times 16 \mathrm{~km}$ level $)$ to $43.8 \%(12 \times 12 \mathrm{~km}$ level $)$ and similar results can be found for the other classes. 


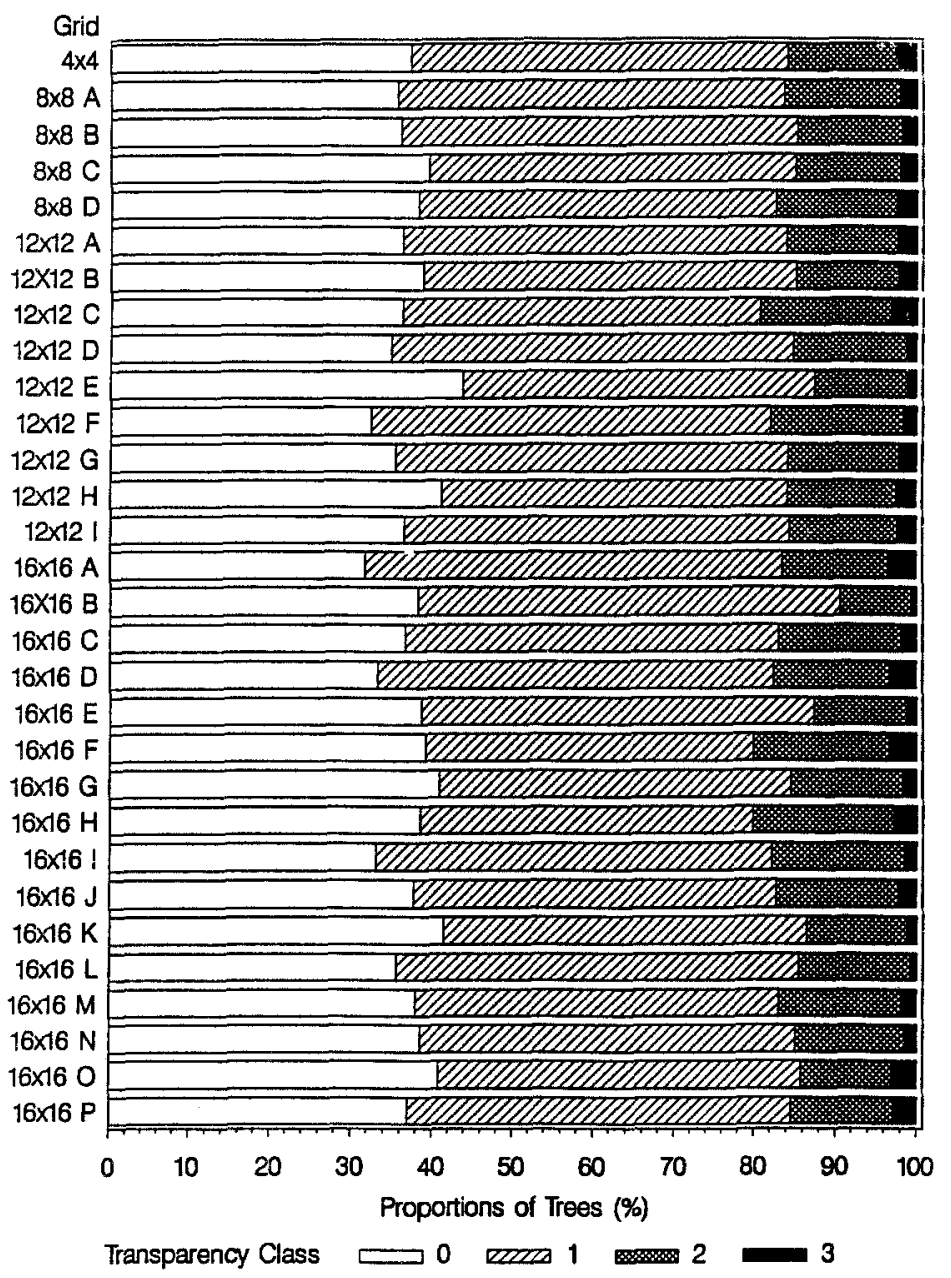

Fig. 1. Proportions of trees in a given transparency category for differing grid densities and differing grids, using the standard method of presentation of such data.

The total population was split into subsets for further analyses. The results for the geographical units are presented in Table IV. Due to the lower number of observations, the variation between the grids is much higher than for the total population. The difference between the estimated proportions is dependent on the grid level and is highest for the $16 \times 16 \mathrm{~km}$ grid level. In a few cases, the range between the maximum and minimum proportion for single classes is more than 70 percent.

The proportions obtained for single tree species are shown in Figure 3. The estimates for spruce and beech show differences of more than 10 percent for single classes, but are relatively homogeneous compared to the results for fir and oak. Differences of more than 30 percent render the results for spruce for the $12 \times 12 \mathrm{~km}$ 


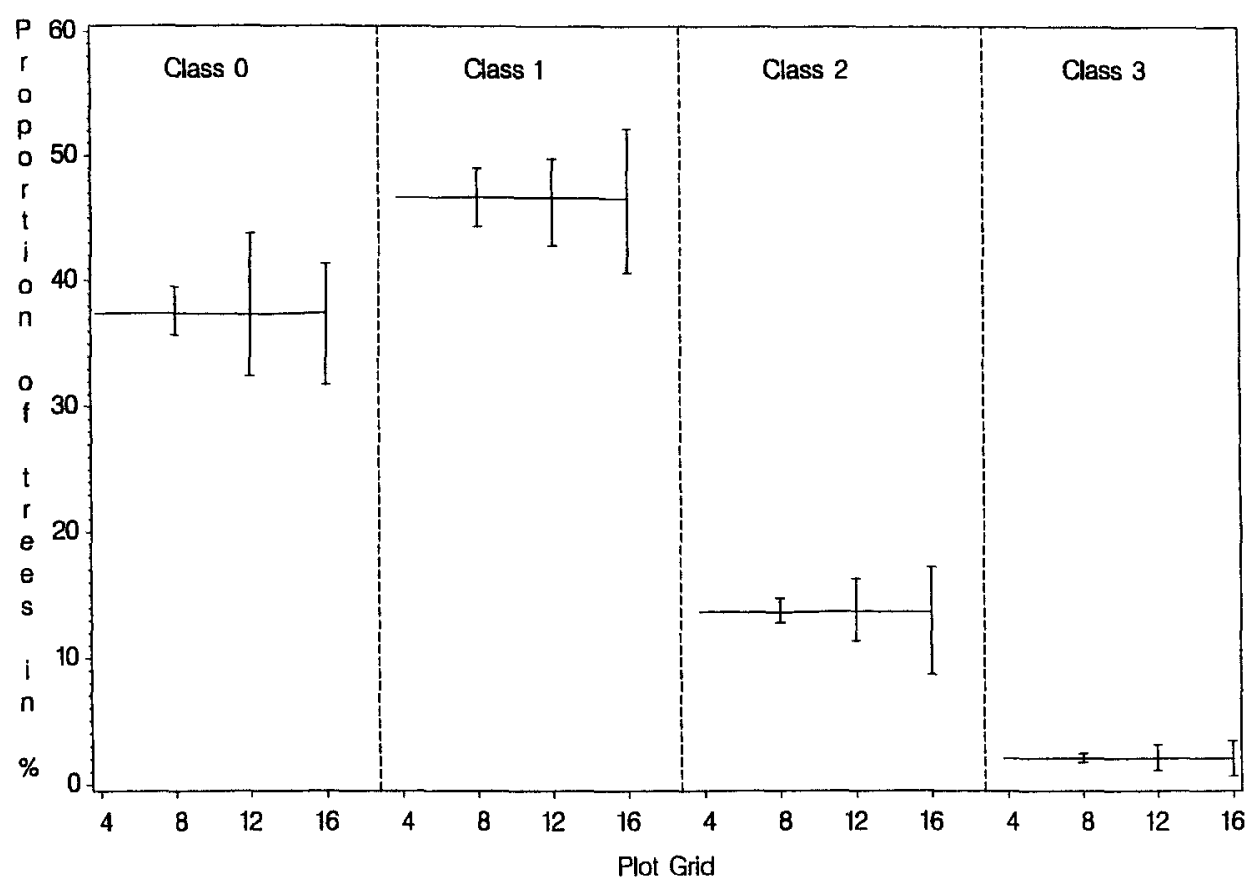

Fig. 2. Mean, maximum and minimum proportions of trees in each transparency class aggregated for grids of differing density.

and the $16 \times 16 \mathrm{~km}$ grid level questionable. The low number of observations for oak makes any interpretation impossible. For example, on one $12 \times 12 \mathrm{~km}$ grid, all trees fall into class 1 whereas on the $16 \times 16 \mathrm{~km}$ grid level the estimates for class 0 vary between 7 percent and 74 percent. More than 60 percent of the observations for oak fall into class 1 on the $4 \times 4 \mathrm{~km}$ grid, in one $16 \times 16 \mathrm{~km}$ grid no observations are found in this class.

The analysis shows that the results for the four transparency classes depend not only on the selected grid level but also on the selected grid. Different grids of the same density level lead to implausible and contradictory results. If a transition to a wider grid is planned in successive surveys, the effect attributable to the selected grid can overwhelm any real change in forest condition.

\subsection{STANDARD ERRORS AND CONFIDENCE INTERVALS}

The interpretation of survey data cannot be based exclusively on the proportions. Statements about the precision of the results are only possible after the calculation of sampling errors and the construction of confidence intervals. However, it is worth noting that the majority of international monitoring programmes concerned with forest health fail to give any confidence estimates or indication of sampling errors. 


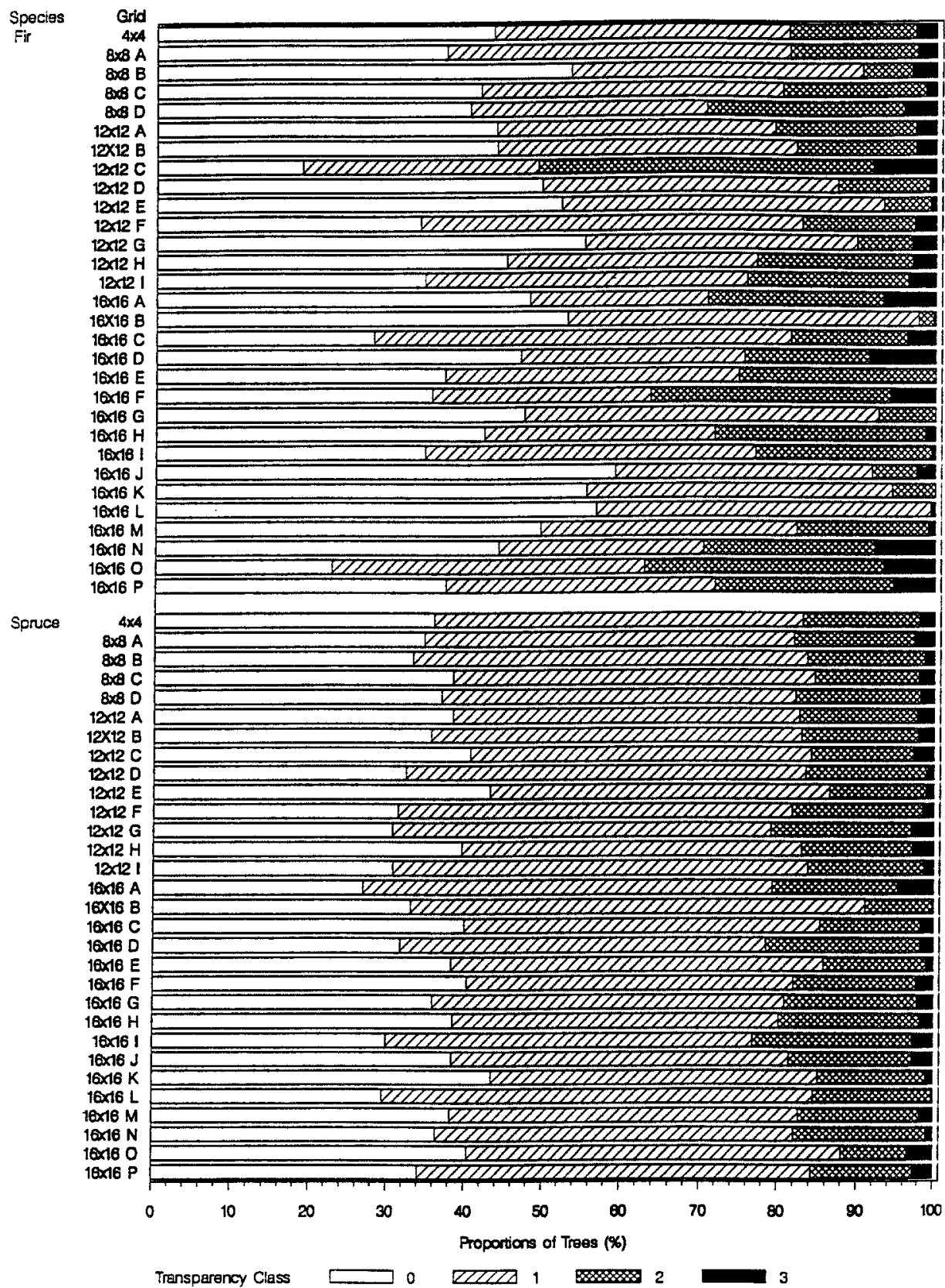

Fig. 3. Proportions of trees in a given transparency category for differing grid densities and differing grids, broken down by species (continued). 
TABLE IV

Estimated proportions (minimum and maximum values) for different grid levels and geographical regions.

\begin{tabular}{llcrrrrrr}
\hline Region & Class & $4 \times 4 \mathrm{~km}$ & \multicolumn{2}{c}{$8 \times 8 \mathrm{~km}$} & \multicolumn{2}{c}{$12 \times 12 \mathrm{~km}$} & \multicolumn{2}{c}{$16 \times 16 \mathrm{~km}$} \\
& & & $\min$ & $\max$ & $\min$ & $\max$ & $\min$ & $\max$ \\
\hline JU & 0 & 37.4 & 34.8 & 39.1 & 26.5 & 47.6 & 24.4 & 53.3 \\
JU & 1 & 45.8 & 44.5 & 47.2 & 35.7 & 55.9 & 29.5 & 60.6 \\
JU & 2 & 15.5 & 13.9 & 16.5 & 9.0 & 24.1 & 8.5 & 23.1 \\
JU & 3 & 1.4 & 1.1 & 1.9 & 0.2 & 6.4 & 0.0 & 4.2 \\
ML & 0 & 45.8 & 39.2 & 53.7 & 26.5 & 61.5 & 29.1 & 60.9 \\
ML & 1 & 45.0 & 38.1 & 48.1 & 33.8 & 59.8 & 20.2 & 61.1 \\
ML & 2 & 7.5 & 6.3 & 9.0 & 2.1 & 15.3 & 1.5 & 18.9 \\
ML & 3 & 1.6 & 0.5 & 4.0 & 0.0 & 5.3 & 0.0 & 8.3 \\
VA & 0 & 41.5 & 37.6 & 45.5 & 32.2 & 53.9 & 23.0 & 100.0 \\
VA & 1 & 43.6 & 35.1 & 49.3 & 35.5 & 53.1 & 0.0 & 60.8 \\
VA & 2 & 13.3 & 10.2 & 17.4 & 9.8 & 17.5 & 0.0 & 25.2 \\
VA & 3 & 1.5 & 0.3 & 2.5 & 0.0 & 3.6 & 0.0 & 8.9 \\
AL & 0 & 32.3 & 30.5 & 35.4 & 20.4 & 39.7 & 25.8 & 44.4 \\
AL & 1 & 48.1 & 46.1 & 50.9 & 42.7 & 55.4 & 40.5 & 57.6 \\
AL & 2 & 16.8 & 14.8 & 18.3 & 11.0 & 20.9 & 11.0 & 24.2 \\
AL & 3 & 2.9 & 1.6 & 4.6 & 1.2 & 4.7 & 0.5 & 6.6 \\
AS & 0 & 26.6 & 16.8 & 40.9 & 11.9 & 44.3 & 4.5 & 60.8 \\
AS & 1 & 56.2 & 49.2 & 62.7 & 35.8 & 75.3 & 28.2 & 90.9 \\
AS & 2 & 14.1 & 7.4 & 20.9 & 7.9 & 21.0 & 0.0 & 33.5 \\
AS & 3 & 3.2 & 1.3 & 7.1 & 1.1 & 6.1 & 0.0 & 10.3 \\
Total & 0 & 37.5 & 35.7 & 39.6 & 32.5 & 43.8 & 31.8 & 41.4 \\
Total & 1 & 46.7 & 44.4 & 49.1 & 42.9 & 49.8 & 40.7 & 52.3 \\
Total & 2 & 13.7 & 12.9 & 14.8 & 11.4 & 16.4 & 8.7 & 17.3 \\
Total & 3 & 2.1 & 1.8 & 2.5 & 1.1 & 3.2 & 0.7 & 3.5 \\
\hline & & & & & & & &
\end{tabular}

As the standard error depends on the number of observations, the precision of the estimates declines when the grid density is decreased. In Figure 4, the standard errors - in percentage of the proportion $p$ - are presented for the four transparency classes and the four grid levels. The values joined by the line are the mean standard errors, the values below and above the line are the minimum and maximum standard errors. As anticipated, the standard errors increase with decreasing grid densities. Equally, the range between the minimum and maximum values increases. Consequently, the precision associated with selected grid levels decreases as the grid widens.

The significance of the standard errors becomes more obvious when the confidence intervals are considered. In Figure 5, the 95\% confidence intervals for the 


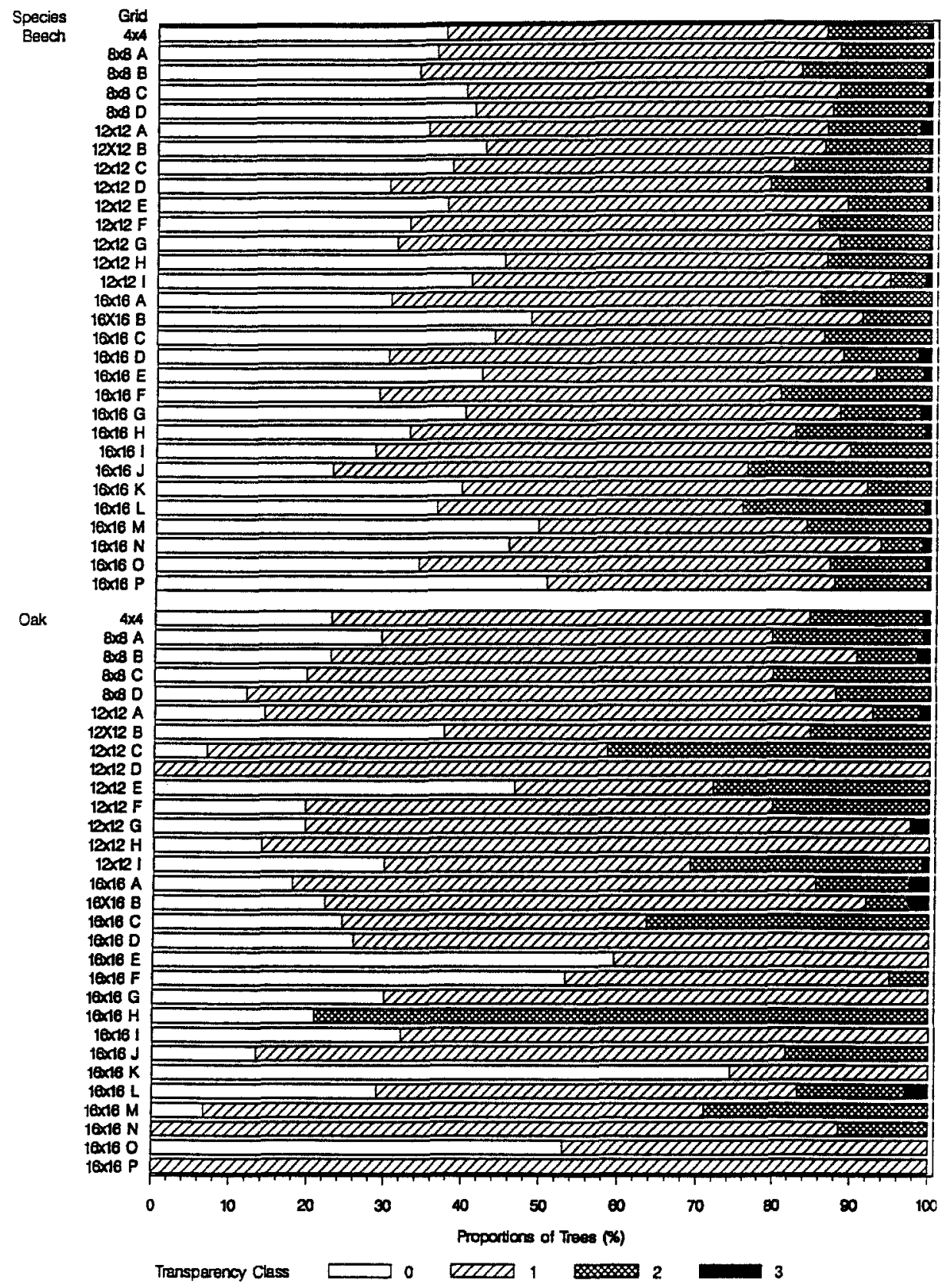

Fig. 3. (Continued).

estimated proportion of trees in class 0 are presented for the total population. The $95 \%$ confidence figure implies that if the sample would be repeated many times, in 


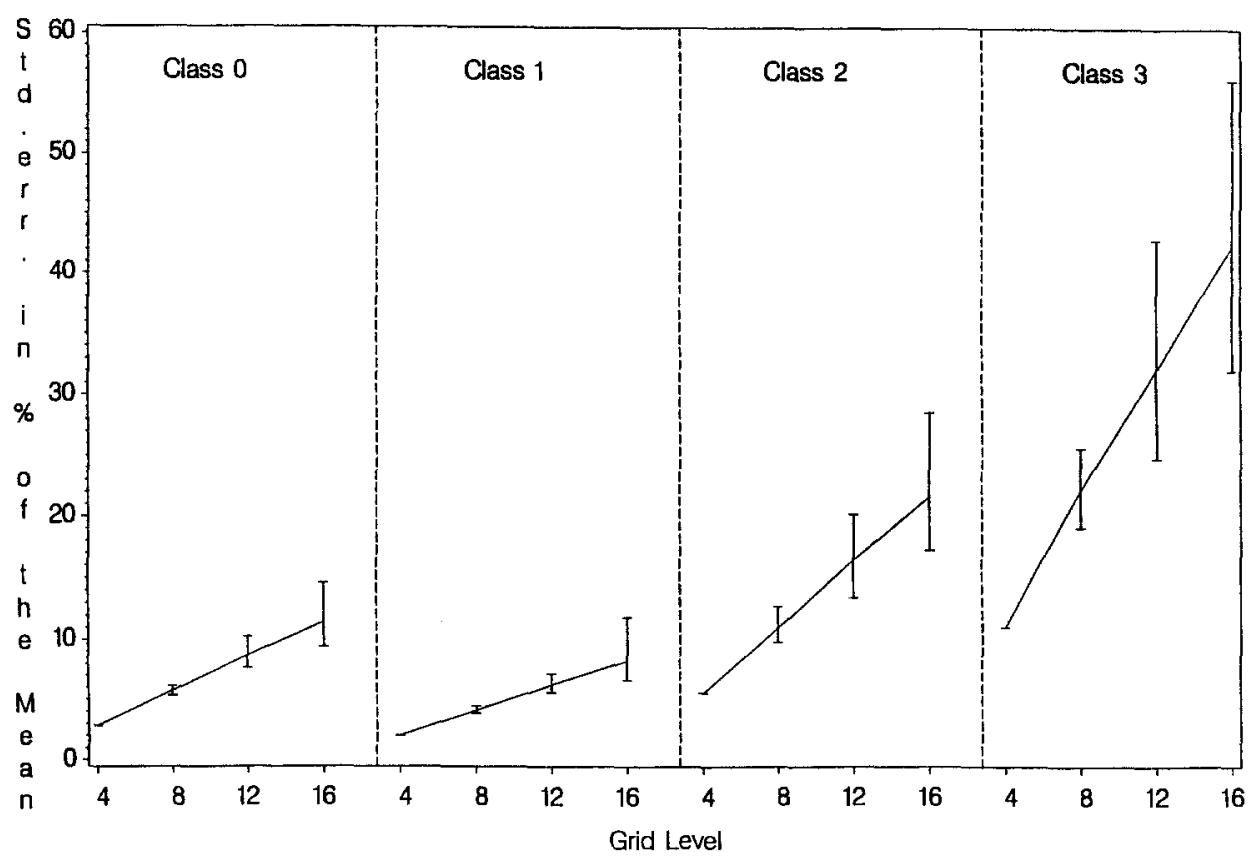

Fig. 4. Mean, maximum and minimum standard errors of the proportions of trees in each transparency class for differing grid densities.

$95 \%$ of the confidence statements the true value of $p$ would be within the confidence limits and, in $5 \%$, the statements would be strong.

The confidence limits for class 0 in the total population cover a range of $6 \%$ on the $4 \times 4 \mathrm{~km}$ grid level. On the $8 \times 8 \mathrm{~km}$ grid level the range is about $10 \%$ and on the $16 \times 16 \mathrm{~km}$ grid level ranges larger than $25 \%$ can be observed. If subpopulations are considered, much wider confidence intervals occur. This is illustrated in Figure 6, where the confidence intervals for the productive region Jura are presented. A maximum width of more than $70 \%$ occurs at the $16 \times 16 \mathrm{~km}$ grid level. The same situation occurs for other subpopulations. As an example, the confidence intervals for beech are shown in Figure 7. The wide confidence intervals for low grid levels makes any interpretation of the results doubtful.

In forest health monitoring, much emphasis is placed on the observation of changes. Changes of proportions between successive years are significant only if they fall outside the confidence limits. If the estimated $p$-values are located within the confidence limits they are random in nature and do not indicate a real change. The confidence intervals presented here for the subpopulations and low grid densities are too wide to enable any meaningful conclusions about changes in the health of the trees. 


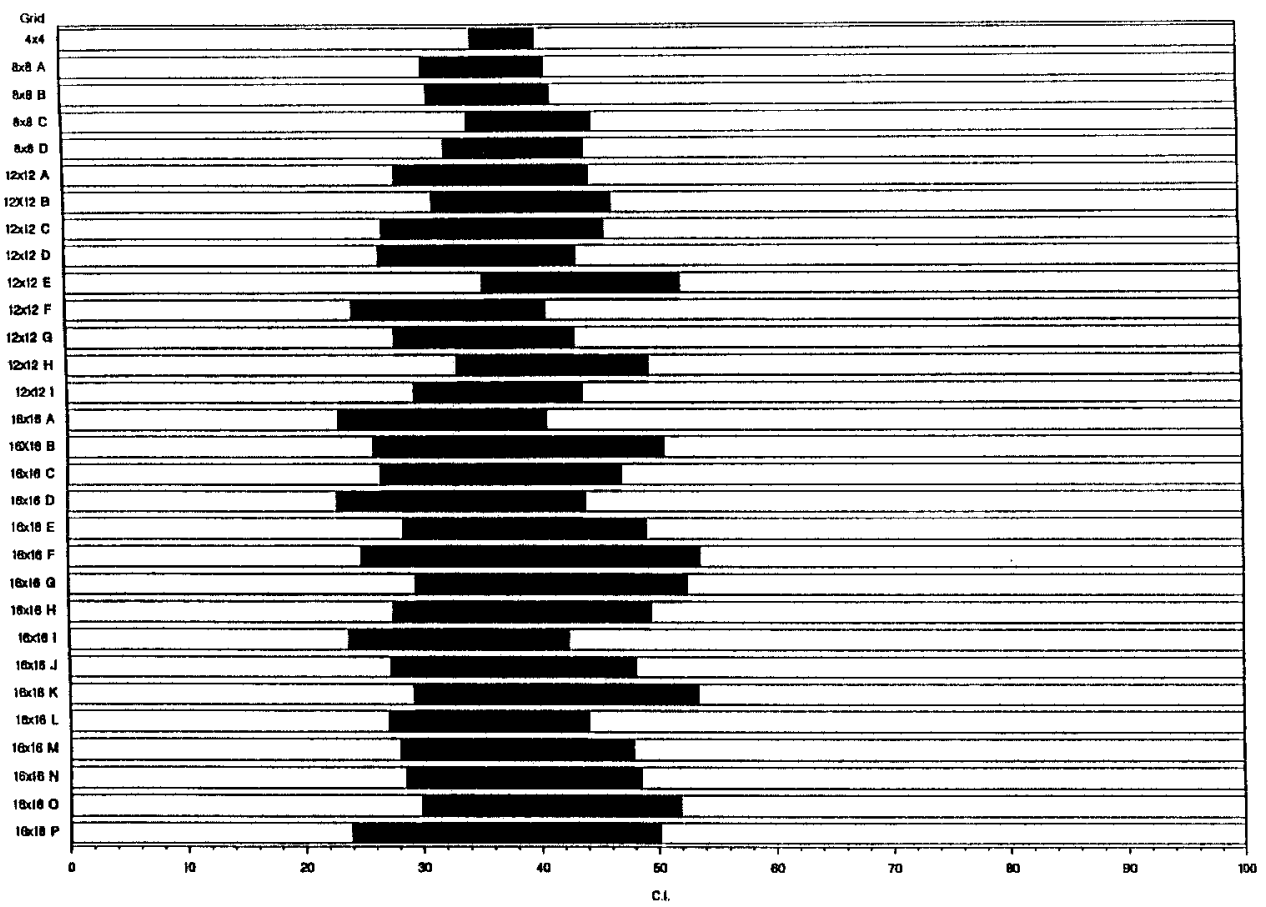

Fig. 5. Confidence intervals $(95 \%)$ for the proportion of trees in class 0 transparency in different grid densities and different grids, using all available data.

\section{Conclusions}

The results clearly indicate the decreasing reliability of the results as the grid density is decreased from $4 \times 4 \mathrm{~km}$ to $16 \times 16 \mathrm{~km}$. However, from a practical viewpoint, it is important to note that the results obtained from the $4 \times 4 \mathrm{~km}$ and $8 \times 8 \mathrm{~km}$ grid for the whole of Switzerland are similar. The width of the confidence intervals is greater, but taking cost-efficiency into account this suggests that the sampling density could be reduced by $75 \%$ without greatly affecting the results. However, further reductions in the sampling density result in a sharp increase in the variability between different grids, suggesting that neither the $12 \times 12 \mathrm{~km}$ nor the $16 \times 16 \mathrm{~km}$ grids would provide reliable data for Switzerland. This conclusion is important given the widespread use of the $16 \times 16 \mathrm{~km}$ grid in national inventories of forest health in Europe.

When broken down by region or by tree species the variability of the results is critical even for some subpopulations assessed on the $8 \times 8 \mathrm{~km}$ grid level. The sample size that is associated with a breakdown in the data affects the sample errors and the confidence intervals. For most of the subsets on the $12 \times 12 \mathrm{~km}$ and the $16 \times 16 \mathrm{~km}$ grid level no reliable results could be presented. If changes of forest 


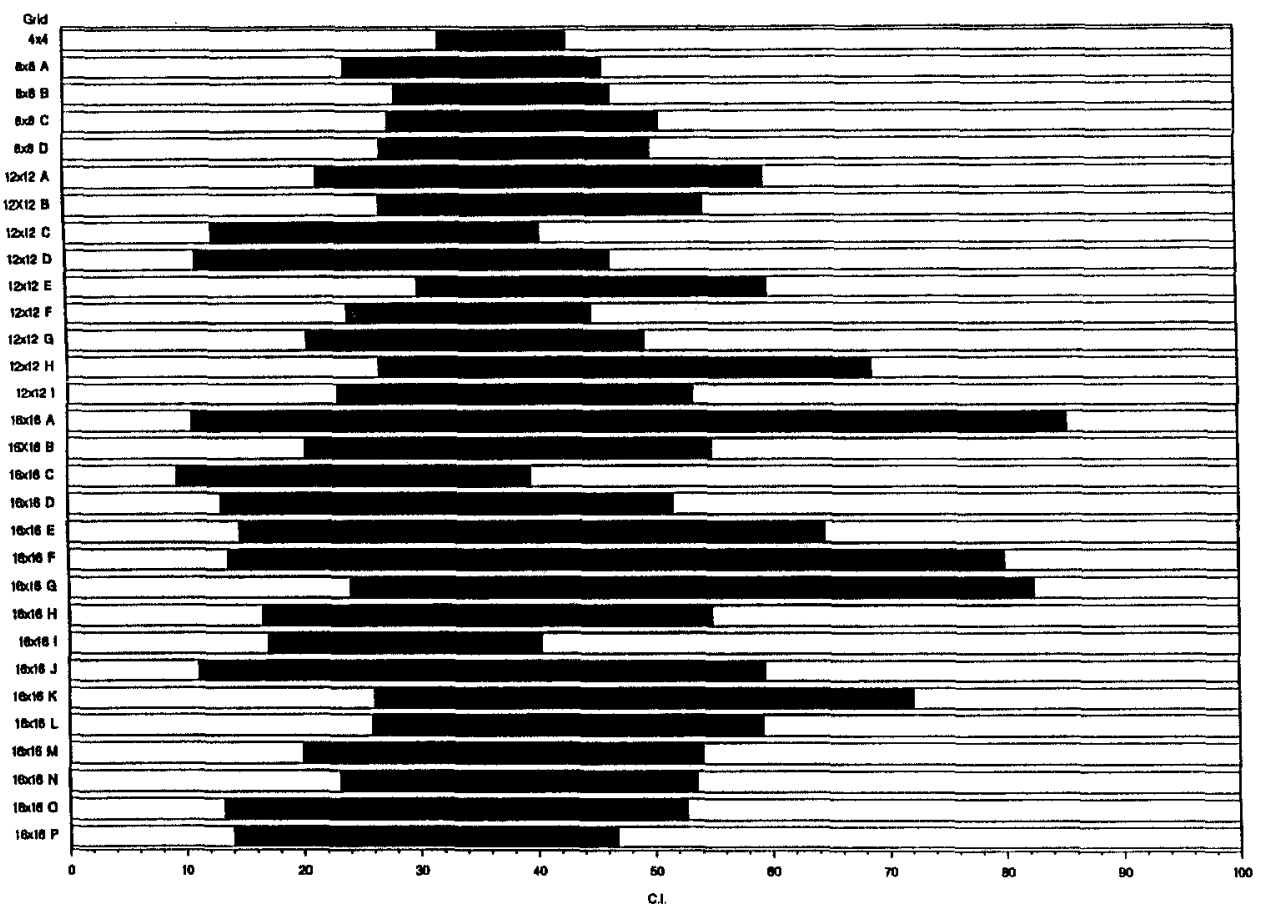

Fig. 6. Confidence intervals (95\%) for the proportion of trees in class 0 transparency in different grid densities and different grids, using data only from the Jura geographical region.

condition have to be assessed, the confidence limits are too wide to guarantee the detection of changes that are meaningful from an ecological point of view.

The result of the different grids were very variable, particularly for the $12 \times 12 \mathrm{~km}$ and $16 \times 16 \mathrm{~km}$ grid levels. When the reduction of sample plots in successive inventories is considered, the selection of the grid is of great importance for the comparability of the results. In some cases changes in forest condition purely attributable to the change in the grid may be observed, in others not. This has serious implications for any proposed changes in the sampling density of forest health monitoring programmes.

\section{References}

Bouhot, L., Landmann, G., and Pierrat, J.C.: 1992, 'Visual Assessment of the Crown Condition of Forest Trees by Surveyors from Six Mediterranean Countries', Unpublished manuscript available from G. Landmann, CRF-INRA, BP35, Champenoux, 54280 Seichamps, France.

Brassel, P. and Schwyzer, A.: 1992, 'Ergebnisse der Waldschadeninventur 1992', in: SanasilvaWaldschadenbericht 1992, BUWAL/Eidgen, Forstdirektion, Bern, Eidgen, Forschungsanstalt Wald, Schnee und Landschaft, Birmensdorf, pp. 7-18.

Burk, R.: 1991, Kategoriale Datenanalyse unter komplexen Design, Universität Freiburg, Mitteilungen der Abteilung Forstliche Biometrie, No. 91-5. 


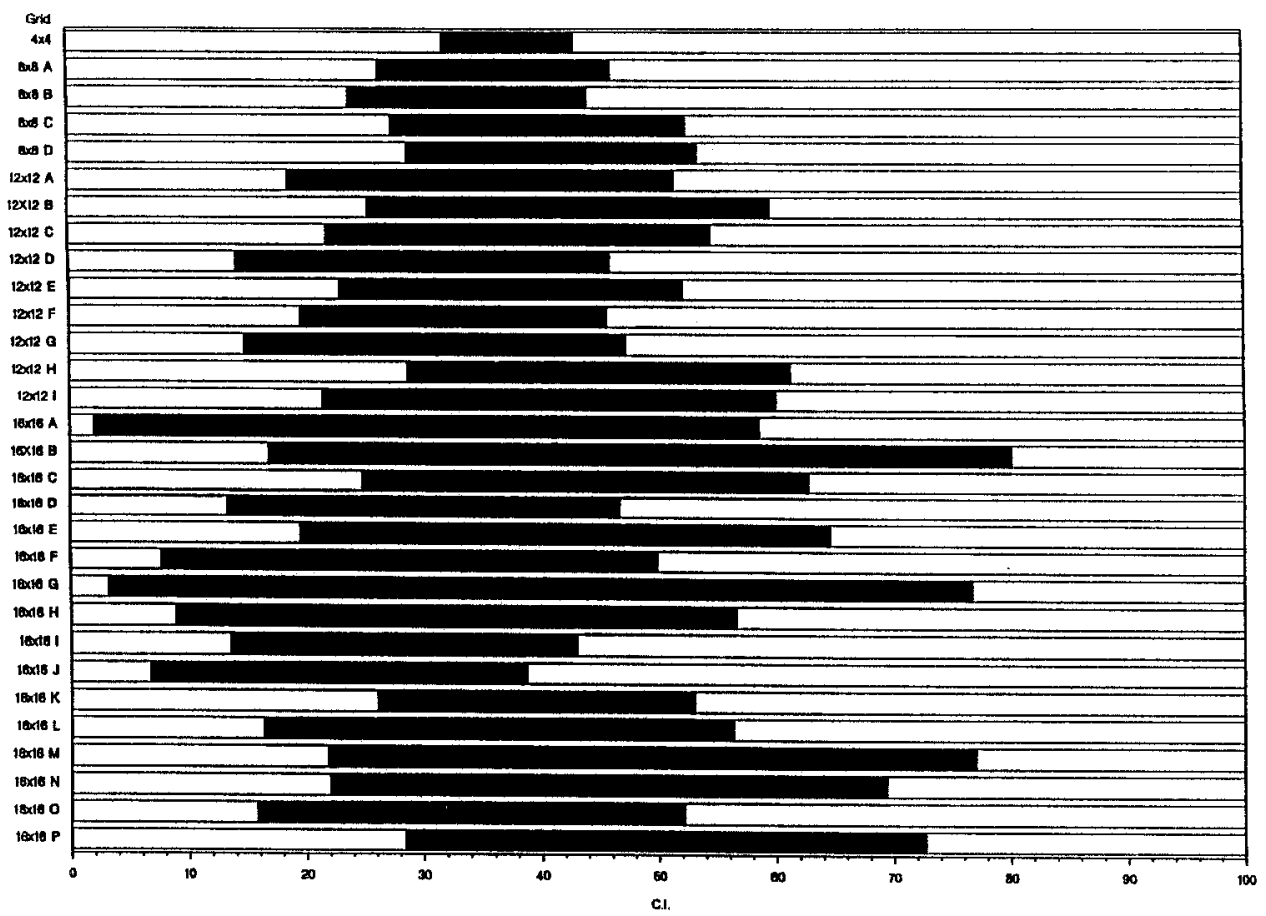

Fig. 7. Confidence intervals $(95 \%)$ for the proportion of trees in class 0 transparency in different grid densities and different grids, using data for beech alone.

Cochran, W.G.: 1977, Sampling Techniques, J. Wiley and Sons, New York.

Dees, M.G.: 1987, 'Einfache statistische Analyse bei ordinaler Skalierung der Schadensvariablen und einer Auswahl der Bäume in Probekreisen', in: Forstliche Biometrie und Informatik, Vorträge anlässlich der 2. Sektionstagung, Mitteilungen der Forstlichen Versuchs- und Forschungsanstalt Baden-Wiirttemberg 142, 85-99.

EAFV: 1988, Schweizerisches Landesforstinventar: Ergebnisse der Erstaufnahme 1982-1986, Eidg. Anst. Forstl. Versuchswes., Ber. 305.

Gold, R.Z.: 1963, 'Tests Auxiliary to Chi-Squared Tests in a Markov Chain', Ann. Math. Statist. 34, $56-74$.

Goodman, L.A.: 1964, 'Simultaneous Confidence Intervals for Contrasts Among Multinomial Proportions', Ann. Math. Statist. 35, 716-725.

Goodman, L.A.: 1965, 'On Simultaneous Confidence Intervals for Multinomial Proportions', Technometrics 7, 247-254.

Innes, J.L.: 1987, 'The Interpretation of International Forest Health Data', in: Perry, R., Harrison, R.M., Bell, J.N.B., and Lester, J.N. (Eds.), Acid Rain: Scientific and Technical Advances, Selper, London, pp. 633-640.

Innes, J.L.: 1988a, 'Forest Health Surveys - A Critique', Environ. Poll. 54, 1-15.

Innes, J.L.: 1988b, 'Forest Health Surveys: Problems in Assessing Observer Objectivity', Can. J. For. Res. 18, 560-565.

Innes, J.L.: 1990, 'Some Problems with the Interpretation of International Assessments of Forest Damage', in: Proceedings of the XIX World Congress of IUFRO, Montreal, Canada, 5-11 August, 1990, IUFRO, Vienna, pp. 380-387.

Innes, J.L., Landmann, G., and Mettendorf, B.: 1992, 'Consistency of Observations of Forest Tree Defoliation in Three European Countries', Environmental Monitoring and Assessment 25, 29-40. 
Innes, J.L.: 1993, Forest Health: Its Assessment and Status, CAB International, Wallingford.

Kish, L.: 1965, Survey Sampling, J. Wiley and Sons, New York.

Köhl, M.: 1990a, 'Sind statistisch signifikante Ergebnisse wirklich signifikant? oder: Gedanken zur Anwendung statistischer Methoden in der forstlichen Forschung', Allg. Forst-und J. Ztg. 161, 226-231.

Köhl, M.: 1990b, 'National Inventories and Inventories of Endangered Forests in Europe', in: V.J. LaBau and T. Cunia (Eds.), State-of-the-Art Methodology of Forest Inventory: A Symposium, Proceedings, U.S. Department of Agriculture, Forest Service, Pacific Northwest Research Station, Portland, Oregon, General Technical Report PNW-GTR-263, pp. 356-365.

Köhl, M.: 1991, 'Waldschadensinventuren: mögliche Ursachen der Variation der Nadel/Blattverlustschätzung zwischen Beobachtern und Folgerungen für Kontrollaufnahmen', Allg. Forst-und J. Ztg. 162, 210-221.

Köhl, M.: 1993, 'Quantifizierung der Beobachterfehler bei der Nadel-/Blattverlustschätzung', Allg. Forst-und J. Ztg. (in press).

Köhl, M. and Gertner, G.: 1992, 'Geostatistische Auswertungsmöglichkeiten für Waldschadeninventuren: Methodische Überlegungen zur Beschreibung räumlicher Verteilungen', Forstw. Cbl, 111, 320-331.

Köhl, M., Kaufmann, E.: 1993, 'Berechnung der Stichprobenfehler bei Waldschadensinventuren', Schweiz. Z. Forstwes. 144 (4), 297-311.

Kublin, E.: 1987, 'Statistische Auswertungsmodelle für Waldschadensinventuren - Methodische Ueberlegungen', Forstw. $\mathrm{Cbl}$. 106, 57-68.

Landmann, G.: 1989, 'La surveillance au sol de l'état sanitaire des forêts: première évaluation rétrospective des résultats françaises (période 1983-1988) et comparaison avec les résultats des pays voisins', in: La Santé des Forêts 1988, Ministre de l'Agriculture et de la Forêt, pp. 33-51.

Lick, E. and Krapfenbauer, A.: 1986, 'Terrestrische Waldzustandsinventuren und Probleme einer Objektivierung', Cbl. Ges. Forstw. 103, 227-241.

Mahrer, F.: 1989, 'Problems in the Determination and Interpretation of Needle and Leaf Loss', in: Bucher, J. and Bucher-Wallin, I. (Eds.), Air Pollution and Forest Decline, Birmensdorf, Eidgenössische Anstalt für das forstliche Versuchswesen, pp. 229-231.

Mandallaz, D., Schlaepfer, R., Arnould, J.: 1986, 'Deperissement des forêts: essai d'analyse des dependences', Ann. Sci. For. 43, 441-458.

Miller, R.G.: 1981, Simultaneous Statistical Inference, Springer Verlag, Heidelberg.

Müller, E. and Stierlin, H.R.: 1990, Sanasilva Kronenbilder mit Nadel-und Blattverlustprozenten, Swiss Federal Institute for Forest Snow and Landscape Research, Birmensdorf.

Neumann, M.: 1989, 'Zu Fragen der Waldzustanderfassung durch grossräumige Inventuren', $\mathrm{Cbl}$. Ges. Forstw. 106, 161-178.

Neumann, M. and Stowasser, S.: 1987, 'Waldzustandsinventur: zur Objektivität von Kronenklassifizierungen', in: Forstliche Bundesversuchsanstalt Wien, Jahresbericht 1986, Vienna: Forstliche Bundesversuchsanstalt, pp. 101-108.

Nicholas, N.S., Gregoire, T.G., and Zedaker, S.M.: 1991, 'The Reliability of Tree Crown Position Classification', Can. J. For. Res. 21, 698-701.

Quesenberry, C.P., Hurst, D.C.: 1964, 'Large Sample Simultaneous Confidence Intervals for Multinomial Proportions', Technometrics 6, 191-195.

Schadauer, K.: 1991, 'Die Ermittlung von Genauigkeitsmaßen terrestrischer Kronenzustandsinventuren im Rahmen der Österreichischen "Waldzustandsinventur"', Cbl. Ges. Forstw. 108, 253282.

Schlaepfer, R.: 1992, 'Waldschadensforschung in der Schweiz', Forum für Wissen, Eidgen. Forschungsanst. Wald, Schnee, Landschaft, WSL, Birmensdorf.

Schöpfer, W., Hradetzky, J.: 1983, 'Zielsetzung, Methoden und Probleme der terrestrischen Waldschadensinventur Baden-Württemberg 1983', Mitteilungen der Forstlichen Versuchs- und Forschungsanstalt Baden-Württemberg 107.

Zar, J.H.: 1984, Biostatistical Analysis, Prentice Hall, Englewood Cliff.

Zingg, A.: 1988, 'Anleitung für die Feldaufnahmen', in: Zingg, A. and Bachofen, H. (Eds.), Schweizerisches Landesforstinventar: Anleitung für die Erstaufnahme 1982-1986, Eidgen. Anst. Forstl. Versuchswes., Bericht 304, pp. 5-118. 